\title{
Messy creativity
}

Article

Accepted Version

Jones, R. (2018) Messy creativity. Language Sciences, 65. pp. 82-86. ISSN 0388-0001 doi:

https://doi.org/10.1016/j.langsci.2017.06.003 Available at https://centaur.reading.ac.uk/81522/

It is advisable to refer to the publisher's version if you intend to cite from the work. See Guidance on citing.

To link to this article DOI: http://dx.doi.org/10.1016/j.langsci.2017.06.003

Publisher: Elsevier

All outputs in CentAUR are protected by Intellectual Property Rights law, including copyright law. Copyright and IPR is retained by the creators or other copyright holders. Terms and conditions for use of this material are defined in the End User Agreement.

\section{www.reading.ac.uk/centaur}

\section{CentAUR}

Central Archive at the University of Reading

Reading's research outputs online 
Messy Creativity

Rodney Jones

University of Reading

"We need to make sure they understand the difference between a weapon and a tool. Language is messy, and sometimes, one can be both."

Dr. Louise Banks, Fictional Linguist in Arrival

In the science fiction movie Arrival (2016), linguist Louise Bank along with the rest of humanity find themselves in a bit of a mess. Twelve spacecraft containing aliens with messy amphibious bodies who speak an unintelligible language expressed through drawing stain-like circles in the air with black smoke have landed in twelve different countries on earth. Banks is charged with making sense of their language in order to discover why they have come. The biggest obstacle to this task, however, proves not to be the aliens, but the inherent messiness of language itself, with its maddening ambiguities and inconsistencies, as well as the messiness of human social systems that stand in the way of the different countries involved cooperating to solve the puzzle. In the end Banks learns that the task of understanding what the aliens want requires more than just linguistic analysis; it also requires intuition and premonition and no small amount of rule-breaking.

The reason I begin with this reference to popular culture in considering the studies of linguistic creativity published in this special issue is that it aptly illustrates the main problem we encounter when we try to analyse linguistic creativity - the fact that both language and creativity are ultimately 'messy', and most of the tools we linguists have at our disposal are designed to detect orderly patterns rather than to confront messiness. As a result of this, many previous studies of linguistic creativity have focused more on the surface intricacies of creative language rather than the messy underbelly of contradictions, contingency, and indeterminacy that these papers attempt to confront. When I speak of the 'messiness' of linguistic creativity, it is not my intention to rehearse romantic notions of the creative artist as someone who is able to 'create order 
out of chaos' (which is, after all, more about 'neatness' than it is about 'messiness'), nor to explore more everyday observations about 'creative people' leading 'messy lives' (Roiphe, 2012) or having 'messy desks' (Vohs, 2013). Rather, I would like to highlight the aspects of 'messy creativity' that are apparent in the articles in this issue, the 'noisy', 'dislocated', even 'unintelligible' quality of some linguistic creativity, and the way it sometimes brings chaos out of order rather than the other way around.

It might be that linguistic creativity has always been messy, but there is a real sense in this collection of essays that much of the creativity in these examples arises out of the cauldron of globalisation, inequality, conflict, and the dizzying developments in communication technologies which have brought about what Sommers (cited by Pratt) calls 'invigorating combinations of beauty and fear, pleasure and unpleasure, certainty and risk, comprehension and incomprehension.' It is a kind of creativity that shakes us out of our comfortable assumptions about the way applied linguistics ought to be carried out, and challenges us to develop 'messy' methods to confront this messy creativity, methods that go beyond trying to 'make sense' of it through traditional conceptual categories and attempt to approach it from the less traditional perspectives of embodiment and entanglement, affect and action.

One messy thing about the linguistic creativity revealed in these papers is that it does not fit so easily into the categories we have developed to talk about either creativity or language. To say something is 'creative' is, above all, to make a value judgement, and the value we assign to something by calling it 'creative' is not just a judgement about its formal qualities or the relative skill it took to make it. It's a judgement about its social worth, about its place within a particular moral universe. In the moral universe that dominates most Western conceptions of creativity, it is invariably associated with ideas like progress, invention, freedom and liberation, an ideological construction of creativity bequeathed to us partly from Enlightenment notions of the individual creative genius as the driver of human progress, and partly from Romantic notions of creativity as the path to 
transcendence and spiritual fulfilment. That's why it's slightly jolting to encounter the sometimes regressive examples of creativity presented here. They are instances of creativity that are either too 'nasty' - like the 'weaponised' racist and homophobic language produced by the rappers that are the subject of Alim, Lee, Mason and Williams's contribution or the scatological slurs of the schoolchildren analysed by Cekaite - too 'noisy' - like the 'incomprehensible' utterances described by Storch, which 'hurl ruined order before our feet' - or too 'normal' like the buttoned down tweets about cricket and weather presented by Gillian, the 'concentrated markers of conformity' offered up by the undocumented immigrants analysed by Pratt, or the creatively 'conventional' language exhibited in the digital writing of South African university students analysed by Deumert. So the first thing that is 'messy' about these instances of creativity is that they 'mess with' our 'semiotic ideologies that construct certain actions as creative' and our 'social ideologies that project some contexts and actions as ... extraordinary and noteworthy' (Deumert this issue). This is a creativity that is often neither progressive nor liberating, sometimes not even particularly 'inventive' in the usual sense of the world. It doesn't bring 'order out of chaos'; rather it rubs our faces in the contradictions of contemporary life and the inadequacy of our bourgeois, overly-intellectual ideas about what constitutes the 'creative'.

Another aspect of messiness apparent in these examples of linguistic creativity is the way they 'mess with' our traditional ideas about language, compelling us to engage with the 'messy interpenetrations and switchings and embeddings and decouplings' (White, 1992: 341) that have come to characterise the 'messy linguistic marketplaces' (Blommaert, 2010) of our fragmented yet interconnected world. Although linguists have long admitted to the messiness of language, their response has always seemed to be to develop tools and concepts to make that messiness seem neat. Even the words we use to describe hybridity, such as code mixing, and the more recent translanguaging, imply more or less orderly, deliberative processes. In the papers in the special issue, such words are replaced with messier, more transgressive terms like code-entanglement, script fusing, enmeshment and infiltration, metaphors which more accurately capture the messy interactions of codes and meanings which characterise many of the examples of 
linguistic creativity represented here. Even more unsettling is the decoupling of code from meaning altogether that we see in the examples of 'noisy creativity' given by Storch, in which utterances derive their power not from meaning but from unintelligibility. But a stubborn refusal to cooperate with conventional ideas of syntax and semantics to some degree characterises almost all of the examples we see here. As Deumert puts it, 'in engaging with language creatively, speakers and writers regularly go beyond the symbolic, the conventional and the referential,' and so, as analysts, we must be willing to do so as well, seeking out ways to 'explore signs as invested with emotion and affect, not simply describing the world, but also expressing our relation to it.'

Taken as a whole, then, what the papers in this issue argue for is the development of a new set of 'messy methods' for understanding linguistic creativity, ways of looking at linguistic creativity that move our attention away from abstract words produced in abstract spaces to an understanding of creativity as a matter of messy assemblages of language, bodies, intentions, emotions, rules, and transgressions.

In his book, After Method: Mess in Social Science Research, the sociologist John Law (2004:2) argues that 'when social science tries to describe things that are complex, diffuse and messy ... it tends to make a mess of it.' He offers four possibilities for the development of methods for 'knowing mess' which, interestingly, articulate with the very orientations suggested by the authors of these papers: 1) knowing as embodiment, 2) knowing as emotionality or apprehension (or, as the authors in these pages put it, knowing as affect and aesthetics), 3) knowing through techniques of deliberate imprecision, and 4) knowing through situated inquiry. All of these forms of knowing, he points out, involve a kind of 're-knowing' of ourselves as scholars, and a rethinking of 'our relations with whatever it is we know, and ... how far the process of knowing it also brings it into being' (Law 2004:3).

One thing that makes these studies of linguistic creativity unique is the extent to which the authors focus their attention on the ways linguistic creativity is embodied. Most of the work on linguistic creativity to date has, not surprisingly, 
focused primarily on language, without sufficient attention to the bodies that produce it and the bodies that hear it. In many of the contributions in this issue, however, the embodied nature of linguistic creativity is front and centre. An important aspect of the verbal duels described by Alim, Lee, Masin and Williams, for example, is the way performers make use of 'gestures, facial expressions, and bodily comportment' as semiotic weapons. Similarly, Cekaite observes how the everyday linguistic play of children cannot be understood through the analysis of language alone, but also requires attention to 'embodied actions, gestures, gaze, laughter, smiles, and repetitions, configured within embodied participation frameworks.' Even the disembodied digitally mediated performances described by Gillian and Deumert call attention to the body through its absence or, more accurately, its displacement (see below). Bodies can serve as carriers of loneliness, rage, despair, and ecstasy in ways that language never can. Bodies can at one moment be the source of intelligible speech, and at the next moment be the source of noise and confusion. They can prop up what we say, or contradict it, as in the anecdote in Pratt's paper about the street corner altercation in which participants say one thing and do another. But verbal creativity does not just emanate from 'messy bodies'; it also creates them, in the form of the overtly racialized figures of Alim, Lee, Mason and Williams's rappers, whose bodily features are used as weapons against them, or in the feminized male body described by the term 'hole of your father', which, as Storch argues, does not just invoke an 'unwanted and dangerous' body, but also disrupts the patriarchal order of the social body. The performance and representation of bodies in discourse is always about more than constructing physical forms; it is about, as Alim, Lee, Mason and Williams remind us, creating, maintaining, or subverting social categories such as those of gender, race, ethnicity, class and national origin. In other words, we use the body as a creative resource, and at the same time create (and destroy) those very same bodies in our social interaction.

Another messy method that these authors experiment with involves confronting the affective dimension of linguistic creativity, which to some degree aligns them with the larger 'affective turn' that scholars in other social sciences are currently navigating (see for example Clough 2010, Massumi 2002). In doing this, to some 
degree they find themselves on familiar ground when it comes to language studies, engaging with what Pratt refers to as the poetic aspects of language, including musicality, dissonance, voice, rhythm, and register. Attention to such aspects of language, Pratt argues, exposes us not just to the affective dimensions of language, but also its political dimensions. 'Linguistic exchanges,' she writes 'are saturated by the micropolitics of style [in which] variation can be a quickstep or a duel, a choreography of risk across whatever social map is in play', a characterisation that as aptly describes the verbal battles reported by Alim, Lee, Mason and Williams as it does the more conventional tweets and texts reported by Gillen and Deumert.

But there are also aspects of the affective turn that put linguists like the scholars represented in this issue on relatively unfamiliar ground. After all, in other social sciences the affective turn has been seen as a reaction to, and somewhat of a rejection of, the linguistic turn that has dominated the social sciences since the 1970s, a way of 'toppling from a privileged position ... linguistic-based structures of meaning making' (Clough 20:2). For many social scientists who have taken this turn, as Wetherell (2013: 349) points out, 'affect is contrasted with the discursive and the cognitive', representing an emphasis on 'processes beyond, below and past discourse' (350, emphasis mine). How far is it possible, then, to conceive of an affective turn in linguistics? How far is it possible for work on affect in language to go beyond the very competent but altogether 'neat' analysis of the linguistic expression of emotion (see for example Dewaele 2010) to embrace the messiness of affect as a method, and how could such a turn contribute to our understanding of the relationship between language and creativity?

The answer is, to some extent, already articulated in much of the literature on affect theory, that is, to understand affect not through the lens of emotion but, as Deumert (this issue) does, through the lens of action and agency, things that applied linguists and discourse analysts do know quite a lot about (for overview see Jones \& Norris 2005). For Spinoza, the patron saint of affect theory, affect is not just about our emotional responses to people, objects, environments, or to the representations we form of them based on our experiences, but rather with 
movement towards a greater capacity for action (Spinoza 1985, see also Deleuze and Guattari 1987). According to Clough (2007:2), 'affect refers ... to bodily capacities to affect and be affected and the augmentation or diminution of a body's capacity to engage, and to connect.' In this regard, it is linked to 'the selffeeling of being alive - that is, aliveness or vitality.' This orientation towards action and connection is reflected in all of the papers in this issue, and especially captured by Pratt in the list of questions she asks scholars of language and creativity to ask themselves:

What gives utterances the ability to generate courage? To move people from one belief to another, to compel action? How does speech emancipate and generate new futures? What qualities give speech the world-making, subject-producing, transformative powers we see exhibited every day?

What affect theory particularly adds to our understanding of social action and agency is the recognition that the capacity to affect and be affected can never be located in the social actor alone: it is always a matter of complex entanglements of actors and objects and environments and their representations. As Barad (2007:139) puts it, phenomena are 'the ontological entanglement of intra-acting agencies.' The main beef that Barad and other affect theorists have with linguistics, as well as with other approaches which they might classify as 'representational', is their tendency to want to separate out these entities, to treat bodies and objects and language as if they can be analyzed separately from one another. This, however, is not a charge that can be levied at the authors of these papers, who demonstrate quite clearly that it is indeed possible to marshal tools from discourse analysis to produce 'textured, lively analyses of multiple modes of engagement ... [which] understand the working of power through patterns of assemblage' (Wetherell 2013: 349, emphasis mine). While our traditional (Western) ways of thinking about action and agency tend to construct distinct entities such as 'subject' and 'object', 'speaker' and 'hearer', 'creator' and 'creation', what the authors of these studies highlight is that these constructions do not work very well when we are confronted with the messy, entangled nature of much linguistic creativity. They reveal what Cekaite, quoting Ingold \& Hallam 
(2007: 20), refers to as 'the limitations of "conceptualizing creativity as a form of invention, exercised by an autonomous individual"', or even as a form of collaboration by separate agentive entities. Agency in creativity, as evidenced in these papers, is distributed in 'messy' ways among the different performers involved, among performers and audiences, and among humans and the tools that they use to create, whether they be physical objects, built environments, digital platforms, or symbolic systems like language, gestures, or clothing. Like affect scholars, they remind us that linguistic creativity arises not from individuals, but from assemblages of 'diverse materials, including language structure, prosody and visible displays, [and] human action' (Cekaite, this issue). It occurs in the context of polylogic participation frameworks in which different human and nonhuman agents constantly shift positions and roles. In fact, the creativity of many of the linguistic productions described in these articles is as dependent on the ways they are listened to, perceived, and responded to, as they are on the way they are produced. Moreover, many of these responses refuse to fit into the conventional patterns of joint 'sense making' that discourse analysts are fond of; they are sometimes more competitive then cooperative, aimed more at scuttling sense making than supporting it. Under the circumstances, the whole notion of what it means to be a performer becomes decentered, by social actors who, in the words of Alim, Lee, Mason and Williams, both perform and are performed into certain kinds of bodies and certain kinds of social identities with different kinds of capacities to affect and be affected.

The third of Law's examples of messy methods that the authors of these articles embrace is what he calls 'deliberate imprecision', which manifests in a less semantic and more metaphorical approach to meaning. This is perhaps best exemplified in the embrace of the notion of indexicality (see in particular the papers by Deumert and Storch), a concept that has migrated to linguistics from semiotics and which seeks to capture the way meanings shift and change as language interacts with contexts and experiences, beliefs and prejudices, and all of the other messy aspects of human social life. Although much of the work on indexicality in sociolinguistics in the past decade has been devoted to understanding how indexical meaning becomes progressively 'solid' or 
'enregistered' in particular communities, other work has highlighted the essentially fragile, and 'messy' nature of indexical meaning (see for example Jones 2013, Joseph 2013, Johnstone and Kiesling 2008), the fact that the concept of indexicality is often better suited to revealing the fundamental indeterminacy of relations between forms and meanings than to resolving it. In fact, following the trails of indexicality formed by some of the examples in these papers reminds one a bit of the parable that Perry (1979) tells as a warning against essentialising indexicals of the messy shopper who follows a trail of sugar through the aisles of the supermarket, trying to catch whoever it is that is making the mess, only to discover that he is the shopper that he is trying to catch. The solution to this dilemma offered by the authors of these papers is not to avoid imprecision but to deliberately traffic in it, to admit that indexical meaning is at its heart the product of metaphorical (or even, as Storch argues, magical) thinking, a way of going beyond the representational or conventionally pragmatic dimensions of language use to explore its essentially 'slippery, indistinct, elusive, complex, diffuse, messy, textured, vague, unspecific, confused, disordered, emotional, painful, pleasurable, hopeful, horrific, lost, redeemed, visionary, angelic, demonic, mundane, intuitive, sliding, and unpredictable' nature (Law 2004:6). In doing so they are answering Johnstone and Kiesling's (2008:29) call for a more 'phenomenological approach to ... social meaning ... that pays particular attention to the multiplicity and indeterminacy of indexical relations and to the way in which such relations arise in lived experience.'

Attention to the more experiential dimension of linguistic creativity naturally entails Law's fourth messy method, knowing through situated inquiry. Nearly all of the papers in this issue champion the importance of understanding linguistic creativity as a situated phenomenon, embedded in particular irreducible and unrepeatable moments of social action (Scollon 2001), and their commitment to this perspective is reflected in the methods they adopt for gathering and interrogating data (as well as their ideas about what counts as linguistic data in the first place). The ethnographic approaches adopted by these authors provide insights into the ways opportunities for creative language use are contingent not just on the immediate social context but also on the broader political context, 
and into the ways linguistic creativity does not just arise out of particular social contexts but plays a role in creating and transforming them.

One of the most striking things about these studies is the way they highlight not just the fact that creative language is always situated, but also the fact that it often functions in ways that mess up these situations and disturb the footing of the people in them. Like the mysterious beings in the movie Arrival, the linguistic creativity described in these pages often seems alien, 'out of place', inserted into contexts where it is not supposed to be. This, after all, is, as Mary Douglas (1966/2002) has argued, the very definition of 'a mess'. The 'out of placeness' illustrated in these papers includes both 'out of place' people - such as the undocumented immigrants in Pratt's article who claim legitimacy by inserting themselves into the most 'normal' of contexts, and the tribal 'outcasts' described by Storch - and out of place language - such as the 'emplacement' of unconventional versions of Arabic in public spaces described by Panović, or the 'out of placeness' of the language of the former colonisers in 'decolonial' contexts described by Deumert, and even the displacement of language from its physical context through the affordances of electronic media described by Gillen. In all of these papers, in fact, situated creativity arises within 'messy' situations of instability, what Pratt in this issue (see also 1991) calls 'contact zones', or what Deumert, quoting Fanon (1963) calls zones of 'occult instability', places that sometimes exist, as do the discursive spaces created by the verbal duels described by Alim, Lee, Mason and Williams, at the risky edge of insult, rupture or violence. At the same time, the linguistic creativity described in these papers is also sometimes difficult for us as scholars to locate or 'situate'. It is never 'just there' for us to analyze, but rather always emergent, contingent, dislocated and improvisational, both playing off and playing with the 'ethics, desires, spaces, manners, meanings, and the assumptions of mutual responsibility' (Pratt this issue) that arise in the moments of their production. If, as Storch (citing Holquist 2014:18) reminds us, a central concept of Bakhtin's metalinguistics 'grows out of his conception of human beings as persons who share the task of being responsible for their own situatedness in a particular time and place' - part of being creative users of language - and effective scholars of linguistic creativity 
- is being responsive to the fact that the whole idea of situatedness is itself often disruptive, disturbing, or just plain 'messy'.

In a recent article in the Guardian, Indian author Pankaj Mishra (2016) writes: 'The stunning events of our age of anger, and our perplexity before them, make it imperative that we anchor thought in the sphere of emotions; these upheavals demand nothing less than a radically enlarged understanding of what it means for human beings to pursue the contradictory ideals of freedom, equality and prosperity.' What the scholars in this issue suggest is that one way to do this is to train our analytical attention onto the everyday moments of linguistic creativity through which these ideals of freedom, equality, and prosperity are worked out, and then to train our gaze back to our precarious positions as analysts, who, like the aliens (and the linguists) in Arrival must operate with our feet planted simultaneously on solid ground and dangling in the murky deep.

References

Barad, K. (2007). Meeting the Universe Halfway: Quantum Physics and the Entanglement of Matter and Meaning. Durham: Duke University Press.

Blommaert, P. D. J. (2010). The Sociolinguistics of Globalization. Cambridge, UK; New York: Cambridge University Press.

Clough, P.T. (2007) Introduction. In P.T. Clough and J. Halley (eds.) The affective turn: Theorizing the social (pp. 1-33). Durham: Duke University Press.

Clough, P.T. (2010) Afterword: The future of affect studies. Body \& Society 16(1): 222-230.

Deleuze, Gilles and Félix Guattari. 1987. A Thousand Plateaus: Capitalism and Schizophrenia. Minneapolis, MN: University of Minnesota Press.

Dewaele, J.-M. (2010). Emotions in Multiple Languages (2010 edition). Houndmills, Basingstoke, Hampshire; New York, NY: AIAA. 
Douglas, M. (2002). Purity and Danger: An Analysis of Concepts of Pollution and Taboo (first published in 1966). London; New York: Routledge.

Ingold, T. and Hallam, E. 2007. Creativity and cultural improvisation: an introduction, pp. 1-24 in Hallam, E. and Ingold, T. (eds), Creativity and Cultural Improvisation, Oxford, Berg

Johnstone, Barbara, \& Scott F. Kiesling (2008). Indexicality and experience: exploring the meanings of /aw/-monophthongization in Pittsburgh. Journal of Sociolinguistics, 12/1, 5-33.

Jones, R. (2013) The paradox of culture in a globalized world. Language and Intercultural Communication 13 (2): 237-44.

Jones, R. and Norris, S. (2005) Discourse as action/discourse in action. In S. Norris and R. Jones (eds.) Discourse in action: Introducing mediated discourse analysis. London: Routledge.

Joseph, J. E. (2013). Alien species: the discursive othering of grey squirrels, Glasgow Gaelic, Shetland Scots and the gay guys in the shag pad. Language and Intercultural Communication, 13(2), 182-201.

Law, J. (2004). After Method: Mess in social science research. London; New York: Routledge.

Massumi, B. (2002) Parables for the Virtual: Movements, Affect, Sensation. Durham, NC: Duke University Press.

Mishra, P. (2016 December 8). Welcome to the age of anger. The Guardian. Retrieved from https://www.theguardian.com/politics/2016/dec/08/welcome-ageanger-brexit-trump

Roiphe, K. (2012). In Praise of Messy Lives: Essays. New York: The Dial Press. 
Sommer, Doris. 2004. Bilingual Aesthetics: A New Sentimental Education. Durham: Duke University Press.

Spinoza, B. d. and E. M. Curley, 1985. The collected works of Spinoza, Princeton, N.J.: Princeton University Press.

White, H. C. (1992). Identity and control: How social formations emerge. Princeton: Princeton University Press.

Vohs, K. D. (2013, September 13). It's Not "Mess." It's Creativity. The New York Times. Retrieved from http://www.nytimes.com/2013/09/15/opinion/sunday/

Wetherell, M. (2013). Affect and discourse - What's the problem? From affect as excess to affective/discursive practice. Subjectivity, 6(4), 349-368. 